\title{
An Overview of Water Pollution Control Strategy
}

\author{
Matome S. Rangata \\ Kola O. Odeku \\ Faculty of Management and Law, University of Limpopo, Turfloop, South Africa
}

\section{Doi:10.5901/mjss.2014.v5n23p976}

\begin{abstract}
Water pollution control strategies continue to be powerful tools being used to ensure safe and clean water. These strategies involve using legal interventions and other approaches to hold polluters accountable and deter others. Pursuant to this, this paper looks at the legislative water control strategies by analysing the relevant laws and considering the impact courts' decisions on water pollution control.
\end{abstract}

Keywords: Control, Pollution, Accountability, Legal interventions, Accountability.

\section{Introduction}

In South Africa, water is one of the most important resources and therefore most valuable natural resources (Turpie et el. 2008). According to Ogolla (1989|) "a country's water resources are important not only for the continued well-being of its population but also because water is a critical element in its economic development. Water is vital for human, animal and plant life. Life cannot exist without it. Most domestic needs in developing countries are satisfied through direct access to natural sources. The World Health Organisation in 1976 estimated that only 38 per cent of the total population in developing countries had access to safe water supplies. This means that 62 per cent of the population resorted to lakes, rivers, streams and wells for domestic requirements. Many industries abstract water from rivers and lakes for their industrial processes and often return it to those sources as trade effluents. Water is a critical factor in agricultural production. In turn agricultural activities create by-products such as sediment loads and chemical residues with adverse impact on water quality." Against the backdrop of the significant of water resources and the impact of pollution it is trite to say that water pollution is a huge challenge in most countries of the world and this need to be curbed using strategic interventions in place for that purpose (Bassi, 2010).

There has been increasing awareness of, and concern about, water pollution all over the world. New approaches towards achieving sustainable pollution control of water resources have been developed internationally (Rogers and Hall, 2003). The prevention of pollution at source, the precautionary principle and the prior licensing of waste water discharges by Department of Water Affairs and Forestry (DWAF) are important strategies for preventing, controlling and reducing water pollution (Dlamini, 2008).

The National Water Act (NWA) Act 36 of 1998, deals extensively with the control of water pollution and degradation of water resources. The state is the custodian of all water resources and discharges its functions under the Department of Water Affairs and Forestry (DWAF). Section 27 of the Constitution provides for the right of everyone to have access to sufficient clean water (Tewari, 2009). Although, DWAF under the supervision of the Minister has been entrusted with the responsibilities of being custodians of water and protecting water from being polluted, it has failed to carry out its responsibilities as required by both the NWA and the Constitution (Mtsweni, 2011). The issue of water pollution control is legislated but, unfortunately, compliance and implementation have not been adequately enforced and monitored (Neysmith, 2010). This study therefore identifies short comings in the water pollution control laws and also identify factors which contribute to failure to ensure compliance, implementation and enforcement of water pollution control laws.

\section{What is Pollution?}

Pollution can be described as the introduction of substance or energy liable to cause hazard's to human health, harm to living resources and ecological systems, damage to structure of amenity, or interference with legitimate uses of the environment by man (Holdgate, 1979). "It is obvious therefore that a country must ensure that its water resources are 
rationally utilised and managed. Such utilisation and management entails the creation of normative and institutional structures, first, to regulate the allocation of an often scarce resource to competing legitimate demands and, secondly, to anticipate, prevent and control the adverse consequences of resources utilisation"(Ogolla, 1989). The South African National Environmental Management Act Act 107 of 1998 in section 1 defines pollution as:-

"Any change in the environment caused by-Substances, Radioactive or other waves; or Noise, odours, dust emitted from any activity, including the storage or treatment of waste or substance, construction and provision of service, whether by any person or an organ of state, where that change has an adverse effect on human well-being or on the composition, resilience and productivity of natural or managed ecosystems or on material's useful to people, or will be such an effect in the future."

\section{Water Pollution Defined}

Water pollution can be defined as contamination of water making it unsafe and unhealthy to people and animals that drink or wash in it (Goel, 2006). It is particularly harmful to people who gets the water directly from the rivers and dams for domestic use and drinking water (Gleick, 2014). In South Africa, fresh water scarcity and quality is caused by increase in water pollution ( Otieno and Ochieng, 2007).

Water pollution is the most serious form of environmental pollution. Water pollution causes huge damage to the environment and the well-being of man (Järup, 2003). The availability of clean freshwater resources is being threatened by contaminations causing gradual decline of safe and clean water (Gleick, 2014). Despite this, many people do not make the efforts to prevent or control water pollution (Allan, 2011).

With regard to South Africa, water resources in global terms are polluted and extremely limited in extent (Fuggle et al. 2009). There is a plethora of legislation in the country dealing with water pollution control. These laws are aimed directly at combating and controlling water pollution in the country; however there is lack of implementation and enforcement of these laws hence, pollution continues to thrive (Steyn, 2008).

Poor communities in the developing countries are vulnerable to water pollution because their rivers are lakes are always affected by industrial dumping and pollution which invariably make the water from the rivers and lakes unsafe for drinking and other activities (Sharma, 1994). Therefore, this study examines water pollution control and strategies using existing legislation that regulates water pollution in South Africa, with the aim of making suggestions on how to effectively use them in order to get maximum results. The overall objective is to achieve a situation where pollution must have been controlled tremendously as a result of implementation and enforcement of water pollution control measures and strategies.

\section{Literature Review}

Section 24 of the South African Constitution Act 108 of 1996 provides that "everyone has the right, to environment that is not harmful to their health or well-being and to have the environment protected for the benefit of present and future generation, through reasonable legislative and other measures that, prevent pollution and ecological degradation, promote conservation and secure ecologically sustainable development resources while promoting justifiable economic and social development." The principles contained in section 24 are echoed in the NWA National Water Act 38 of 1998, in section 2. One of the objectives of the Act is the protection of the environment by managing water resources. Section 3(2) stipulates that the Minister of Water Affairs and Forestry must, in the allocation of water use rights, see to environmental protection. Any water authority may require that a water user must apply for a license if polluted water is to be released in a water source, if the water is polluted in any other way or water is used in such a way that the quality of the water is detrimentally affected. Lack of adequate sanitation and inadequately maintained or inappropriately designed systems constitute a range of pollution risks to the environment, especially to surface and ground water resources, which in turn pose a threat to health.

The prevention of water pollution in South Africa is primarily regulated by the National Water Act 36 of 1998. One of its primary objectives is to reduce degradation of water resources in terms of Section 2(h). Section 19 of this Act imposes certain obligations, it states that an owner, controller, occupier or user of land on which anything that has caused or is likely to cause pollution of water resources takes place must take reasonable measures to stop such pollution or prevent it from happening.

Even though the main aim of the Water Act is to reduce water pollution, the Act cannot achieve water pollution control there are other pieces of legislation and common law principles that talk directly to the issues of water pollution control. One of the common law principles stipulate that everyone who sees a possibility that his conduct could lead to 
pollution of water and could affect other people should take measure to minimize or prevent such pollution of water (Stein, 2009). Therefore, everyone has the responsibility to control pollution of water in the country by behaving responsibly.

The NEMA, provides in section 2 that the most important development is to promote the Integrated Pollution Control (IPC) and this is the statutorily concretised in the NEMA which lays down the following fundamental principles relevant to IPC that:

"The polluter-pays principle, a cornerstone of pollution and waste minimization in that it holds that those responsible for environmental damage and adverse impacts on human health should pay the costs of mitigating and rehabilitating damage caused (Section 2(4)(I) of the Act).

The preventive principle, which NEMA sets out as "that pollution and degradation of the environment [be] avoided, or, where they cannot be all together avoided are minimised and remedied Section 2(4)(a)(ii) of the act.

The precautionary principle, which the NEMA sets out that a risk-averse and cautious approach is, applied which takes into account the limits of current knowledge about the consequences of decisions and action Section 2(4)(a)(vii)."

Section 28 of the NEMA requires an owner of land, or a person in control of land, or a person who occupies or uses the land, on which any activity or process is or was performed or undertaken; or any other situation exists, which causes, has caused, or is likely to cause pollution of water resource, to take all reasonable measures to prevent any such pollution from occurring, continuing or recurring.

The Environmental Conservation Act 107 of 1998, (ECA) does not lay down standards specifically but is nevertheless relevant to IPC as the statutory general environmental policy 73 and provides that

"In the first instance pollution, of whatever nature, should be prevented by formulating effective comprehensive policy, the promulgation of appropriate legislation, the establishment and maintenance of norms and standards, the application of the best practical environmental options based on the most suitable available technology, the fostering attitudes among industrialists and public and participation in international co-operation."

A national strategy for IPC will be developed in which the elements of treatment and re-use will enjoy priority. Disposal into the atmosphere, land and water environments should be limited to acceptable levels and standards- GN 51 in the government gazette No:15428 dated 21 January 1994. Protection against hazardous waste, the control of environmentally detrimental agriculture trade or industrial practices and the promotion of recycling is included in the strategy- GN 51 in the government gazette No:15428 dated 21 January 1994. The policy declared under the ECA includes a provision pertinent to water pollution. It promotes the preventative approach and the need for a national strategy such as the NWRS.

The Health Act 63 of 1977, requires every local authorities to adopt all lawful, necessary and reasonably practicable measures to prevent the occurrence of any unhygienic and offensive condition which will or could be harmful to the health of any person within its district or the district on any other local authority. Although, this act places certain duties on government officials, there is lack of implementation resulting to negligence and people being exposed to unsafe water causing various water diseases such as cholera and diarrhea.

Section 20(1)(b), of this Act further requires, every local authority to prevent the pollution of any water intended for the use of the inhabitants of its district, irrespective of whether such water is obtained from sources within or outside its district, or purify water which has become polluted- Sections $(5,34,36 \mathrm{~A}, 37,38,39)$. This is done by granting all local authorities power to take all lawful and reasonable practicable measures to prevent any condition which will or could be harmful to health of any person within its district or the district of any other local authority. The Act further grants the minister power to make regulations controlling water pollution- Section 20(1).

The Conservation of Agricultural Resources Act 43 of 1983, regulates water pollution from farming operationsSection 6(1)(n)F. Most of the farming operation uses hazardous chemicals that are used to treat the soil and kill insects and sometimes due to soil erosion, these chemicals are washed into the river and streams and pollute the water. It is the responsibility of farmers to ensure that these chemicals are not going to end up in the rivers because of the harm that they can cause to the animals and people who drink water from such river (Conway and Pretty, 2013).

Under the Water Act 54 of 1956, a set of regulations are provided for water pollution offences arising out of mining operations- Section 26. See GNR 287 in GG 4989 of 29 February 1976. They provide for the prevention of water pollution such as failure to prevent run-off, failure to protect waterways, the sitting of water dumps and failure to repair dumps. These regulations are that mines must:-

(a) Inform DWAF of new activities on the mine, incident of spillage threatening water resources and cessation of activities.

(b) Place restrictions on the use of certain materials.

(c) Require that pollution control dams have one in fifty years flood capacity. 
(d) Specify requirements for technical investigations and monitoring.

The Minister of Water Affairs has warned that "South Africa could face crisis of water within the next decade if urgent steps to prevent water pollution and enforcement of water pollution control laws are not taken. She further outlined that if there is no proper administration of water pollution control laws South Africa will run out of clean water 13 years from now" (Molewa, 2012).

The scenario of poor water due to pollution is a phenomenon prevalent all over Africa (Moyo. 2011). Water pollution has affected water quality and impacted negatively on public health and the ecosystem. The report by Moyo (2011) suggests that the main sources of water pollution are untreated or partially treated effluents from municipal and industrial and mining waste. Water discharges, and run-off from small scale mining operations have impaired the quality of water in the South African Democratic countries which includes South Africa. This further indicates the lack of implementation of the laws and regulations that governs water pollution control in the country.

In the case of Cambridge Water Co v Eastern Counties Leather plc- Court of Appeal (Sir Stephen Brown, president, Lord Justice Mann and Lord Justice Nolan), 19 Where the court found that spillages of chemicals polluted and contaminated ground water and the reliefs of injunction and damages in respect of the pollution of ground water sought by the plaintiff was granted. The rule, which made a person liable for the event of an escape of something non-natural which he had brought onto his land, rather than for his actions, was inapposite to the present case, where liability attached by reason of the defendant's actions in spilling chemicals.

\section{Water Pollution Control Strategies}

The post-Apartheid reforms in South Africa has put in place the existing water framework and strategies intended to redress the disparities inherited from the prior racial segregation policies which had prevented and denied particularly, black communities access to clean and fresh water. (Francis 2003). Water pollution is making water to be scarce and impacting on the access to clean and safe water (Francis 2003). To reverse these inequalities and injustices, government has focused on water reform strategies as part of its reconstruction and development (WPSS 1994.

Water policy, strategies and laws are supported by national environmental legislation in seeking to balance the use of natural resources for social and economic development, with the need to ensure that natural resources such as water are not unacceptably degraded and rendered of diminished value and preserved for future generations (Grey and Sadoff, 2007).

The NWA which was enacted in 1998 is the principle legal instrument on water resources. This act transformed South Africa's water legal framework by setting forth a comprehensive agenda for water pollution control in the country (Lorimer, 2012). The main purpose of the Act is to ensure that the nation's water resources are protected, used, developed, conserved, managed and controlled in ways which take into account almost other factors meeting basic human needs of present and future generations. These include promoting equitable access to water; promoting the efficient substance, and beneficial use of water in the public interest and facilitating social and economic developmentArticle 2 NWA.

In many parts of South Africa, water has been over utilised, ( Maitre et al. 2002). This is because South Africa depends mainly on surface water resources for most of its urban, industrial and irrigation requirements ( Maitre et al. 2002). The use of water is dominated by irrigation, amounting for over $60 \%$ of the total water use in the country, the bulk of which is used consumptively. Water requirements for urban and domestic use account for nearly $30 \%$, with the remainder being used for mining, bulk industries and as cooling water for power generation (Basson, 1997). The quality of many water resources in South Africa have been deteriorated to the extent that their capacity to support human use have been reduced (Basson, 1997). An assessment of water pollution control strategies become important in order to showcase their effectiveness, weaknesses and identify areas for improvement and strengthening for sustainable safe water provision.

\subsection{National Water Act}

The NWA provides framework for water resources assessment. Chapter 12 of the Act requires the establishment of national monitoring systems on the country's water and national information systems to address the monitoring, assessing and dissemination of information on all water resources in the country (Malzbender et al. 2009). The implementation of this framework is comprehensively addressed in the National Water Resources Strategy of 2004 (NWRS). There is therefore the need to increase the implementation of framework in order to reduce the risk of polluted water resources (Nepfumbada and Muller, 2012). 
Chapter 12 of NWA is relevant to water pollution control because it provides that 'ongoing monitoring and assessment of the patterns of water use, are critical for effective water pollution control and protection', and should be based on sound scientific and technical information and understanding (Nomquphu et al. 2007). The monitoring and information management function is defined as a national government competency, specifically regarding DWAF, whose responsibilities include: national design and coordination of monitoring programmes; development of technology and methods to support monitoring, assessment and auditing (Nomquphu et al. 2007).

\subsection{National Water Resource Strategy}

The National Water Resource Strategy 2004 (NWRS) sets out government plans for water resources management at the national level. The strategy was published in 2004 by the national government in order to regulate water pollution in the country. It also aims to provide an indicative multi-year programme for implementing the national water policy and an indicative quantification of government proposed investments in all aspects of water resources including water pollution control.

South Africa's national policy and legislation for water resources are based on an integrated approach to managing the quality and quantity of surface water and ground water (Jønch-Clausen and Fugl, 2001). The need to protect water resources from unacceptable degradation is balanced with the need to use water for social and economic development (Wallace and Acreman, 2003). The NWRS describes in broad, the way in which water resources of the country should be protected. It does this by creating awareness of the importance of water resources in sustainable development and also putting a balance between protection and development of water resources and ensuring adequate supply of water and water security for socio-economic development. Through the NWRS it is believed that integrating the management of the resource of water quality perspective is key to success of preserving South Africa's water and preventing it from being polluted (Wallace and Acreman, 2003).

Though the NWRS can be seen as the cornerstone of all the strategies that are intended in controlling water pollution and degradation of the country's water, its plans cannot be fully implemented due to lack of financial resources and skillfully qualified individuals to educate the nation on the importance of protecting water and ensuring that water pollution (Wallace and Acreman, 2003).

Proper implementation of water policy cannot be achieved overnight ( Molle, 2008). Planned steps have to be taken for proper water policy (Mollinga, 2008 ). The most important aspect is that implementation of water policy should start occurring now as preparation for the future, this will minimise water problem that we are currently encountering (Pahl-Wostl et al. 2008). Continuous and gradual implementation of water pollution control strategies will lead to prevention of water pollution.

\subsection{Water resource management strategy}

The Water Resource Management Strategy of 2004 (WRMS) is derived directly from the NWA; there are basic principles that can be seen underlying this strategy in the NWA. The principle of unity of the hydrological cycle does not include a distinction between surface and ground water but subsumes all water resources, which are all linked to each other- At article 1(1)(xxvii) of the NWRS.

This strategy requires that water management plans be based on the principle of integrated management in order to achieve sustainability, equity and efficiency. According to DWAF, integrated water resource management takes into account the amount of available water either surface or ground water, water quality, environmental and social issues as an integrated whole to ensure sustainable, equitable and efficient use of water in the country.

The WRMS is related to water pollution control because its mission is to manage ground water quality in an integrated and sustainable manner within the context of NWRS to provide adequate level of protection to groundwater resources and secure the supply of water of acceptable quality. It is through this mission that it is believed that WMRS will play a key in ensuring that groundwater is less polluted and its quality is protected at all costs (Owusu-Asante and Ndiritu, 2009).

Proper implementation of the WRMS will give the country an idea as to how much of the country's water is polluted and what measures should be taken in order to prevent such pollution or degradation of water. It is however clear that the mission of the WRMS is yet to be realised. 


\subsection{National Water Conservation and Water Demand Management of 2004 (WCWDM)}

This strategy forms part of the NWRS. The WCWDM strategy seeks to promote the efficient water use to all water sectors (Sonjica, 2004). Although elements of this strategy have already been implemented, a wide spread monitored implementation plan is yet to take place (Sonjica, 2004). South Africa has developed water laws to ensure priority of clean water allocation for basic water needs ( Sullivan, 2009). The government under the department of water affairs has set up projects to determine the basic human needs for clean water and environmental water reserve (Sullivan, 2009). Though it is anticipated that within the next five to ten years the water reserves will be determined for all the areas in the country, this will be realisable if the level of pollution and contamination is reduced drastically ( Sullivan, 2009)

Though NWA controls and protects the countries water from being polluted, majority of people in South Africa do not have access to clean water. Examples, Carolina residents in Mpumalanga who cannot afford bottled water have resorted to drinking the town's polluted water to quench their thirst (Anaman, 2013). Many have fallen ill and ended up in local clinics and hospitals. This is because the town water had been polluted by chemicals from old and abandoned mines (Maziya 2012). In Venda, a rural area in the Limpopo Province of South Africa, many people live without access to clean drinking water because of failure of government to properly implement water pollution control laws in ensuring that water is protected from any form of pollution (Harshfield 2009).

Water pollution control has not been effective as a result of lack of proper implementation of water pollution control strategies by DWAF entrusted with the responsibilities of implementing these strategies. This ineffectiveness is largely due to lack of proper infrastructure and proper facilities needed for optimum water pollution control (Schreiner et al. 2011).

Those who are most affected by water pollution are those that do not have adequate access to clean water in their homes and end up relying on polluted river water for most of their daily needs (Cosgrove and Rijsberman, 2014). Implementation of pollution control strategies should be a continuous process until it reaches zero tolerance level.

\section{Conclusion}

Water pollution control is essential in order to preserve the existing water so that it will be suitable for human livelihood. There is tendency in man to pollute, therefore, the regulatory frameworks should be used to control and remedy the situation. To this ends, to some extent, legal interventions have proven successful. But it should be noted that while legal interventions are appropriate, other measures such as common law principles should also be applicable in order to control and prevent water pollution.

\section{References}

Allan T 2011. Virtual water: tackling the threat to our planet's most precious resource. IB Tauris \& Co Ltd, London, UK.

Anaman GE 2013. Groundwater problems and management strategies-a critical review of the groundwater situation in Johannesburg. From http://wiredspace.wits.ac.za/handle/10539/13663. (Retrieved 11 May, 2013).

Bassi MP 2010. Ethical Issues of Water Resource Management in a Changing Climate: Equity and Legal Pluralism in Chile. From https://scholarsbank.uoregon.edu/xmlui/handle/1794/10620. (Retrieved 29 June 2013).

Basson MS, Van Niekerk PH, Van Rooyen JN 1997. Overview of Water Resources Availability and Utilization in South Africa. Report No. P RSA/00/0197. Department of Water Affairs and Forestry and BKS (Pty) Ltd., Pretoria, South Africa.

Conway GR, Pretty JN 2013. Unwelcome harvest: agriculture and pollution.

Earthscan, London, UK.

Cosgrove WJ, Rijsberman FR 2014. World water vision: making water everybody's business. Earthscan, London, UK.

Dlamini TH 2008. An environmental liability and risk management approach to landfill groundwater quality monitoring in South Africa. From http://wiredspace.wits.ac.za/handle/10539/4938. (Retrieved 14 July, 2013).

Francis R 2003. Water Justice in South Africa; Structural policy at the intersection of Human Rights Economics and Political Power. Georgetown International Review, 18:149:157.

Fuggle RF, Rabie MA, Strydom HA, King ND 2009. Environmental Management in South Africa. Juta \& Co, Cape Town, South Africas.

Gleick PH 2014. The World's Water Volume 8: The Biennial Report on Freshwater Resources. Island Press, Washington, USA.

Gleick PH 2014. The World's Water Volume 8: The Biennial Report on Freshwater Resources. From http://books.google.co.zal books?hl=en\&lr=\&id=psl8agaaqbaj\&oi=fnd\&pg=pr2\&dq= $65 w x c b c f f j \&$ sig=ulcocsmdiculoyzmbga8e9svdns\#v=onepage\&q\&f=false. (Retrieved 11 October, 2014).

Goel PK 2006 . Water pollution: causes, effects and control. From http://books.google.co.za/books?hl=en\&lr=\&id=4r9 cyyoifccc\&oi= fnd\&pg=pa2\&dq= ficya11uew\&sig=iwfx_dpztfxww0g9t9mq_eu69hy\#v=onepage\&q\&f=false ( Retrieved 19 April, 2013).

Grey D, Sadoff CW 2007. Sink or swim? Water security for growth and development. Water Policy, 9: 545-571. 
Harshfield E 2009. Water Purification in Rural South Africa: Ethical Analysis and Reflections on Collaborative Community Engagement Projects in Engineering. From http://www.virginia.edu/jpc/docs/WaterPurificationSouthAfrica2010.pdf. (Retrieved 11 July, 2013).

History Teaching Review Yearbook, 2008. From https://dspace.stir.ac.uk/handle/1893/2317. (Retrieved 2 June 2013).

Holdgate MW 1979. A perspective of Environmental Pollution, From http://books.google.co.uk/books/about/. (Retrieved 1 July, 2013).

Järup L 2003. Hazards of heavy metal contamination. British medical bulletin, 68 (1):167-182.

Jønch-Clausen T, Fugl J 2001. Firming up the Conceptual Basis of Integrated Water Resources Management. International Journal of Water Resources Development. 27(4): 501-510.

Le Maitre DC, van Wilgen BW, Gelderblom CM, Bailey C, Chapman RA, Nel JA 2002. Invasive alien trees and water resources in South Africa: case studies of the costs and benefits of management. Forest Ecology and Management. 160(1-3): 143-159.

Lorimer B 2012. Some, for all, forever: A Case Study of Participation in Water Management in South Africa's Umgeni River Catchment. From http://yorkspace.library.yorku.ca/xmlui/handle/10315/20830. (Retrieved 22 September, 2013).

Malzbender D, Earle A, Deedat H, Hollingworth B, Mokorosi P 2009. Review of regulatory aspects of the water services sector. From orangesenqurak.com. (Retrieved 22 January 2014).

Maziya Z 2012. Carolina residents in Mpumalanga who cannot afford bottled water have resorted to drinking the town's polluted water to quench their thirst. From http://www.timeslive.co.za/scitech/2012/02/16/carolina-mpumalanga-residents-drinking-polluted-water. (Retrieved 11 May, 2013).

Molle F 2008. Nirvana concepts, narratives and policy models: Insights from the water sector. http://www.ibcperu.org/doc/isis/mas/ 8850.pdf. (Retrieved 18 September, 2013).

Mollinga PP 2008. Water Politics and Development Cooperation. From http://link.springer.com/chapter/10.1007/978-3-540-76707-7_1\#. (Retrieved 4 September, 2013).

Moyo N. Mining law guide for masters students the University of Limpopo for the year 2011.

Mtsweni DK 2011. The perceptions of municipal water service officials on the Blue Drop programme: the case of Nkangala District Municipality. From http://dspace.nwu.ac.za/handle/10394/8388. (Retrieved 15 May, 2013).

Ndiritu J 2009. The simple modelling method for storm-and grey-water quality management applied to Alexandra settlement. From http://www.scielo.org.za/scielo.php?pid=S1816-79502009000500010\&script=sci_arttext. (Retrieved 19 November, 2013).

Nepfumbada MP, Muller H 2012. Of document: Draft National Water Resource Strategy 2 (NWRS-2). From http://db3sqepoi5n3s. cloudfront.net/files/docs/120911comprehensive_0.pdf. (Retrieved 2 January 2014).

Neysmith J, Dent M 2010. Non-statutory barriers and incentives to stakeholder participation in reducing water pollution: A South African case study. From http://www.scielo.org.za/scielo.php?pid=S1816-9502010000500007\&script=sci_arttext\&tlng=pt. (Retrieved 22 June, 2013).

NWRS 2004. National Water Resource Strategy was published in 2004 in the Republic of South Africa.

Ogolla BD1989. Water Pollution Control in Africa: A Comparative Legal Survey.

Journal of African Law. 33(2): 149-156.

Otieno FAO, Ochieng GMM 2007. Water management tools as a means of averting a possible water scarcity in South Africa by the year 2025. http://www.bing.com/search?q= 2025\&form=CMDTDF\&pc=CMDTDF\&src=IE-SearchBox\&adlt=strict. ( Retrieved 15 May, 2013).

Pahl-Wostl C, Tàbara D, Bouwen R, Craps M, Dewulf A, Mostert E, Ridder D, Taillieu T 2008.The importance of social learning and culture for sustainable water management. Ecological Economics. 484-495.

Rogers P, Hall AW 2003. Effective water governance. From http://dlc.dlib.indiana.edu/dlc/handle/10535/4995. (Retrieved 14 March, 2013).

Schreiner B, Chimuti S, Cupido A, Mbanda V 2011. Towards Water Resources Regulation in South Africa. From http://pegasysinstitute. org/wp-content/uploads/2014/04/1842Vol1.pdf. (Retrieved 4 July, 2013).

Sharma BK 1994. Water pollution. From http://books.google.co.za/books?hl=en\&lr=\&id=R8HtwoFsOogC\&oi=fnd\&pg=PA29\&dq= Mg2EqixwZR\&sig=3eqnCc_ypjiq31jHfe4m4mOxtCs\#v=onepage\&q\&f=false. (Retrieved 2 September, 2013).

Sonjica B 2004. Water Conservation and Water Demand Management Strategy. http://www.dwaf.gov.za/docs/Other/Water UseConservation/WCWDMimpAug04.pdf. (Retrieved 11 May, 2013).

Steyn P 2008. Industry, Pollution and the Apartheid State in South Africa History Teaching Review Yearbook, 2008. From https://dspace.stir.ac.uk/handle/1893/2317. (Retrieved 2 June 2013).

Sullivan C 2002. Calculating a Water Poverty Index. World Development, 30(7): 1195-1210.

Tewari DD.. A detailed analysis of evolution of water rights in South Africa: An account of three and a half centuries from 1652 AD to present. Water SA, 35(5): 693-710.

Trawick P 200. Against the Privatization of Water: An Indigenous Model for Improving Existing Laws and Successfully Governing the Commons. World Development, 31(6): 977-996.

Turpie JK, Marais C, Blignaut JN 2008. The working for water programme: Evolution of a payments for ecosystem services mechanism that addresses both poverty and ecosystem service delivery in South Africa. Ecological Economics, 65(4): 788-798.

Wallace JS, Acreman MC 2003. The sharing of water between society and ecosystems: from conflict to catchment-based comanagement. From rstb.royalsocietypublishing.org. (Retrieved 24 May, 2013).

WPSS 1994. South Africa, White paper on water supply and sanitation policy (1994); South Africa. From http://www.dwaf.gov.zal Documents/Policies/WSSP.pdf. (Retrieved 24 April, 2013). 